\title{
STUDENTS' MATHEMATICAL COMMUNICATION SKILLS BASED ON KEIRSEYS' PERSONALITY TYPES OF IDEALIST AND GENDER
}

\author{
Indah Dwi Mulyastuti $^{{ }^{*}}{ }^{*}$, Budiyono $^{1}$, Diari Indriati ${ }^{1}$ \\ ${ }^{1}$ Postgraduate School of Mathematics Education, Universitas Sebelas Maret, Indonesia \\ *Email: indahdwimulyastuti@gmail.com
}

\begin{abstract}
Abstrak: Pembelajaran pada abad 21 dapat diartikan sebagai pembelajaran yang memberikan keterampilan pada abad 21, salah satunya adalah komunikasi. Pembelajaran matematika memungkinkan siswa untuk mengkomunikasikan ide-ide matematika dengan jelas. Tipe kepribadian yang berbeda dapat mempengaruhi cara mereka berkomunikasi, dan aktivitas lain dalam belajar matematika. Penelitian ini bertujuan untuk mendeskripsikan kemampuan komunikasi matematis siswa ditinjau dari tipe kepribadian Keirsey yaitu Idealist dan gender yang memiliki kepribadian Idealist. Penelitian ini menggunakan penelitian kualitatif deskriptif dan dilaksanakan di Sekolah Menengah Pertama Negeri 1 Purwodadi pada tahun pelajaran 2019/2020. Penelitian dilakukan pada subjek kelas VIII I dengan tipe kepribadian idealis, kemudian dipilih 1 siswa perempuan dan 1 siswa laki-laki dengan menggunakan purposive sampling. Peneliti merupakan instrumen penelitian utama dengan bantuan pedoman observasi, angket, tes kemampuan komunikasi matematis dan kemudian wawancara. Teknik pengumpulan data adalah teknik triangulasi dengan membandingkan jawaban tes keterampilan komunikasi matematis dan wawancara. Reduksi data, penyajian data dan penarikan kesimpulan merupakan teknik analisis data yang digunakan dalam penelitian ini. Siswa perempuan dengan tipe kepribadian idealis berkomunikasi lebih baik secara matematis daripada siswa laki-laki dengan tipe kepribadian idealis seperti yang ditunjukkan pada hasil penelitian ini.
\end{abstract}

\section{Kata kunci : Keterampilan komunikasi matematis, Kepribadian idealis, Jenis kelamin}

\begin{abstract}
Learning in the 21st century can be defined as learning that provides 21 st century skills, one of which is communication. Mathematics learning allows students to communicate mathematical ideas clearly. Different personality types can affect the way they communicate, and other activities in learning mathematics. This study aims to describe students' mathematical communication skills in terms of Keirsey personality types, namely Idealist and gender who have Idealist personalities. Descriptive qualitative research was used in this research and was carried out at Junior High School Negeri 1 Purwodadi in the 2019/2020 school year. The research was conducted on the subject of class VIII I with idealist personality type, then selected 1 female student and 1 male student using purposive sampling. The researcher is the main research instrument with the help of observation guidelines, questionnaires, tests of mathematical communication skills and then interviews. The data collection technique is a triangulation technique by comparing the answers to the mathematical communication skills test and interviews. Data reduction, data presentation and drawing conclusions are data analysis techniques used in this study. Female students with idealist personality types communicate better
\end{abstract}


mathematically than male students with idealist personality types as shown in the results of this study.

Keywords : Mathematical communication skills, idealistic personality, Gender.

\section{INTRODUCTION}

Mathematics plays a strategic role in the progress of all aspects of life. Various areas of life require mathematics to communicate well, think mathematically, have logic, and reason. Mathematics taught from elementary school to college is proof that mathematics plays a strategic role in the advancement of life. Mathematics learning is in accordance with the current 2013 curriculum development, one of which is based on a shift in the 21 st century learning paradigm. Learning that provides 21 st century skills is usually said to be learning 21 according to the 2013 curriculum, known as 4C: 1) Communication, 2) Collaboration, 3) Critical Thinking, and 4) Creative. One of the goals of learning mathematics in schools is to develop communication skills. The objectives of learning mathematics that must be achieved by students as a general goal of learning mathematics are problem solving, reasoning, communication, connection, and representation (NCTM, 2000).

The ability to convey mathematical ideas, both orally and in writing can be said as mathematical communication skills. A person's skills to provide explanations or write down reasons for any mathematical argument used to solve mathematical problems using mathematical terms, tables, diagrams, notations, or formulas correctly and checking or evaluating other mathematical thinking (Sari, Kusnandi, \& Suhendra., 2017). Not only expressing ideas through writing in mathematical communication skills, but more broadly, for example, students' skills in speaking, explaining, describing, listening, asking, explaining, working together (sharing), writing and finally reporting what has been learned (Sulvian \& Mousley., 1996). Speaking, listening, discussing, and exchanging opinions are some examples of oral mathematical communication skills. Meanwhile, expressing mathematical ideas through pictures / graphs, tables, equations, or in students' language is a written mathematical communication skill (Hodiyanto, 2017).

Based on observations at Junior High School Negeri 1 Purwodadi, it can be seen that some students have difficulty expressing their ideas in written form and have not been able to determine what concepts should be used to solve math problems. Students also experience confusion when they have to interpret the information presented on the questions in the form of writing, pictures, graphs, diagrams or other mathematical symbols. On the other hand, through mathematical communication, students can reflect, clarify, and broaden ideas and understand their mathematical relationships and arguments (The literacy and Numeracy Secretariat, 2010). 
The process of learning mathematics really requires communication skills, because through communication students are able to convey their mathematical ideas and clarify understanding. Communication is a way of sharing ideas and clarifying understanding (Rahmayani, 2014). Students can express problem-solving ideas through mathematical communication, develop strategies and mathematical solutions both in writing and orally (Pratiwi, 2015). Given the importance of mathematical communication skills, a teacher must at least provide problems that train mathematical communication skills by taking into account the various characteristics of students and gender differences. The different characteristics are called personality types (Boroujeni \& Hasanimanesh, 2015) There are different characteristics in the learning process (Aziz, 2014). Differences in characteristics allow for differences in the mathematical abilities of students. With the teacher's awareness of the different conditions of each student, the teacher can provide the best teaching method for each student's personality type regarding mathematical abilities, one of which is mathematical communication skills.

There are many personality type theories. One of them is David Keirsey's personality type theory. According to this theory, personality types consist of guardian, rational, artisan, and idealist. The idealist personality type is the type who likes to complete tasks personally rather than group discussions (Keirsey $\&$ Bates, 1984). This type always wants to increase self-use and this type can see problems from various perspectives. Enjoys reading, and also likes writing. Therefore, idealists are less suited to the form of objective tests, because they cannot reveal the ability to write. Creativity is a very important part of an idealist. However, the idealist personality type in making written conclusions in their own language is still not quite right (Melya \& Supriadi, 2018). Large classes are very disturbing to idealists in learning, because they prefer small classes where the members know each other.

In addition to those related to personality types, one of which is the idealist personality type in mathematical communication skills, there are several studies that have been conducted regarding mathematical communication skills which are influenced by gender differences. Differences in the sex of students (gender) can result in differences in the psychology of learning of students (Nugraha \& Pujiastuti, 2019). Gender differences not only affect the ability in mathematics but also acquire knowledge of mathematics itself (Aliyah, Yuhana, \& Santosa, 2019).

Research conducted by Wijaya, Sujadi, \& Riyadi (2016) concluded that written communication skills on male subjects tended to use unordered steps, scribble a lot, write only important answers, and did not pay attention to aesthetics. Meanwhile, the female subject tends to use sequential and systematic steps, neat and clear writing, almost no scribbles, and writing fairly complete answers. Several previous studies have not found the results of research on mathematical communication skills based on idealistic 
personality types and gender, so that motivating researchers to conduct research which is expected to improve mathematical communication skills.

Based on the description of the background, students' mathematical communication skills based on idealistic personality types and gender are the objectives of this study.

\section{METHODS}

This type of research is descriptive qualitative. This research was conducted in class VIII I of SMP Negeri 1 Purwodadi in 2019/2020. The research subjects consisted of 1 female student with idealistic personality and 1 male student with idealistic personality. After obtaining the idealist personality type subject, the researcher will test mathematical communication skills with 3 questions according to the indicators. The indicators in this study were developed from the models of Cai, Lane and Jocobsin (Fachrurazi, 2011) are 1) able to write mathematically, make sense, be clear and structured logically and systematically when providing an explanation of the answers to questions for writing communication indicators; 2) able to paint pictures, diagrams and tables completely and correctly for drawing communication indicators; 3) able to model mathematical problems correctly, then perform calculations or get complete and correct solutions for mathematical expression communication indicators. The technique of taking the subject in this study using purposive sampling. The data used were observation, questionnaires, tests of mathematical communication skills and interviews as data collection instruments with the researcher as the main research instrument. Research data collection techniques are a) observation, data collection by direct observation; b) questionnaire, conducted to determine the personality type; c) tests, carried out in writing to research subjects according to mathematical communication indicators; d) interviews, are used to determine mathematical communication skills. The validity of the data was carried out using the triangulation method, namely comparing the written test data and interviews. The data analysis used was data reduction, data presentation and conclusion drawing.

\section{RESULT AND DISCUSSION}

The research was conducted in three stages to obtain data. The first stage is a Keirsey personality type questionnaire, the second stage is a test of mathematical communication skills and the third stage is an interview. Based on the classification of personality types carried out in class VIII I, there are 8 guardian students, 5 rational students, 7 artisan students, and 10 idealistic students. Data collection can be done after finding one female student with an idealist personality type and one male student with an idealist personality type. The list of student names to be studied in this study is shown in Table 1 . 
Table 1. The names of research subjects

\begin{tabular}{lcc}
\hline No & Initials Name & Gender \\
\hline 1 & FAP & F \\
2 & FYP & M \\
\hline
\end{tabular}

Female student with an idealist personality type

The results of the mathematical communication skills test on the first subject of female students with the idealist personality type are shown in Figure 1-Figure 3.

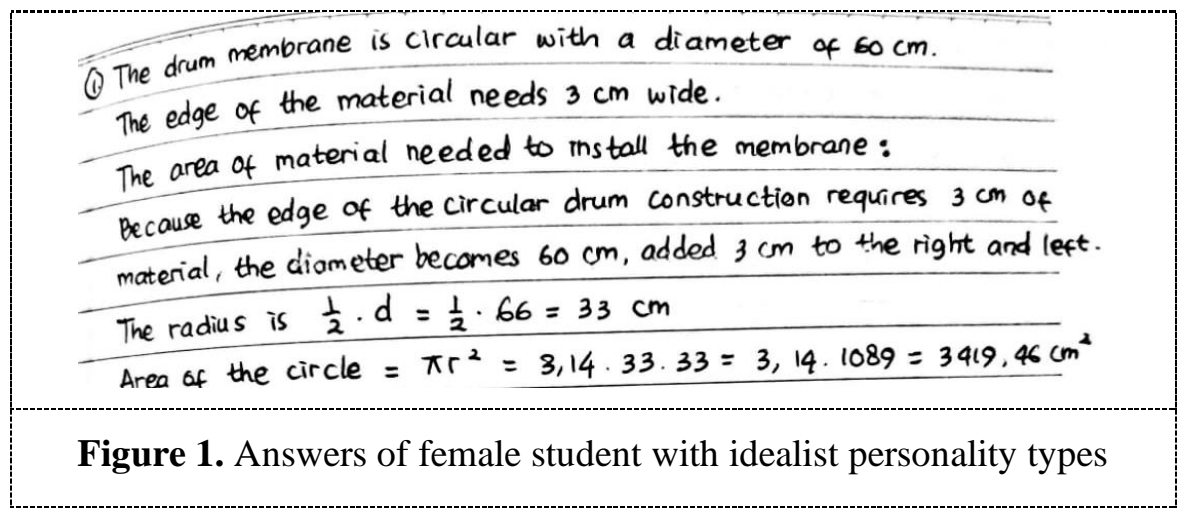

Based on Figure 1, it can be seen that student describe more words when taking steps to understand the problem of a circular drum membrane with a diameter of $60 \mathrm{~cm}$ which will be covered with material and the edge of the drum membrane is given $3 \mathrm{~cm}$ of material. She can explain in writing that before determining the material needed to cover the circular drum membrane, you must find the area of the circle, then determine the diameter first, the diameter of the material to be used to cover the drum membrane is obtained from the drum diameter added by $3 \mathrm{~cm}$ to the right and $3 \mathrm{~cm}$ to the right. left. She can determine the radius of the circle from the diameter obtained, then calculates the area of the circle. However, the she does not provide a conclusion to these problems. In general, she is able to write steps systematically, providing explanations in their own language so that there is a lack of symbolic communication in solving these problems. "I don't know the symbols in math very well, so I had to ask my colleagues first." be a statement expressed by the subject and in accordance with the answer to the question. 


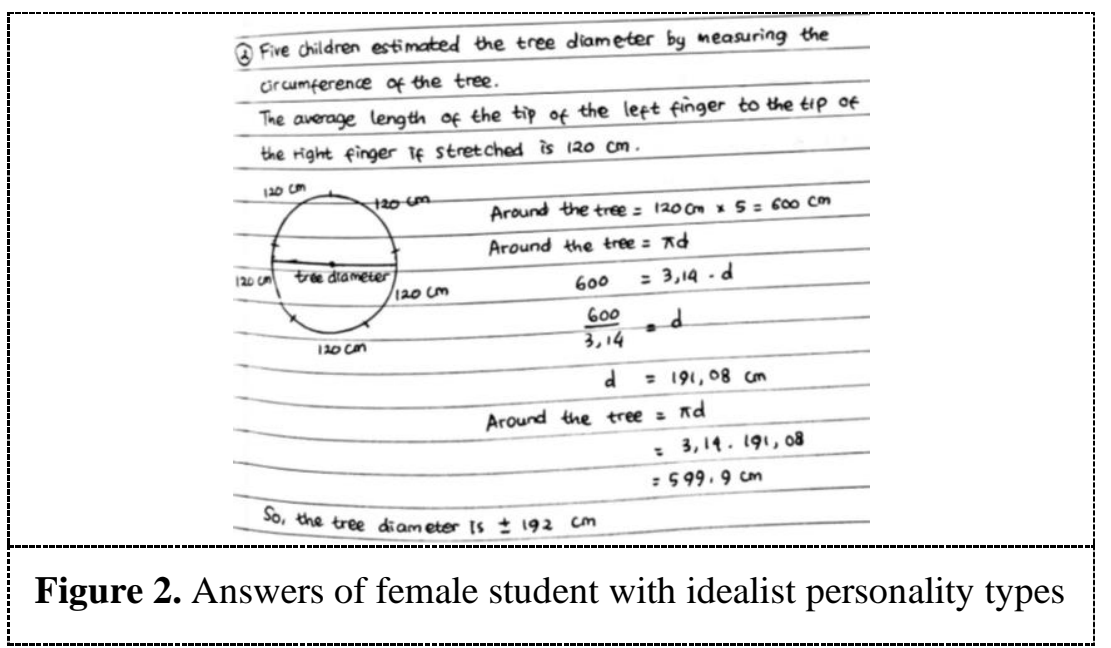

Figure 2 shows that she can express its ideas about the information obtained in the problem so that it is able to illustrate the image of a circle formed of five children surrounding a tree by stretching their arms and fingertips touching each other. She draws clearly, then determines the perimeter of the tree from the illustration that has been drawn. She is also able to describe the steps to solve the problem and the steps to double-check the answers that have been obtained, so that the She becomes more confident with the answer and provides a conclusion on the diameter of the tree. Such a result is based on the statement where it says: "I can draw a circle easily using a circular object that is a coin in my pocket, because the answer I get is a decimal so I am not sure, and finally double-check it by calculating the circumference of the diameter. I got. "

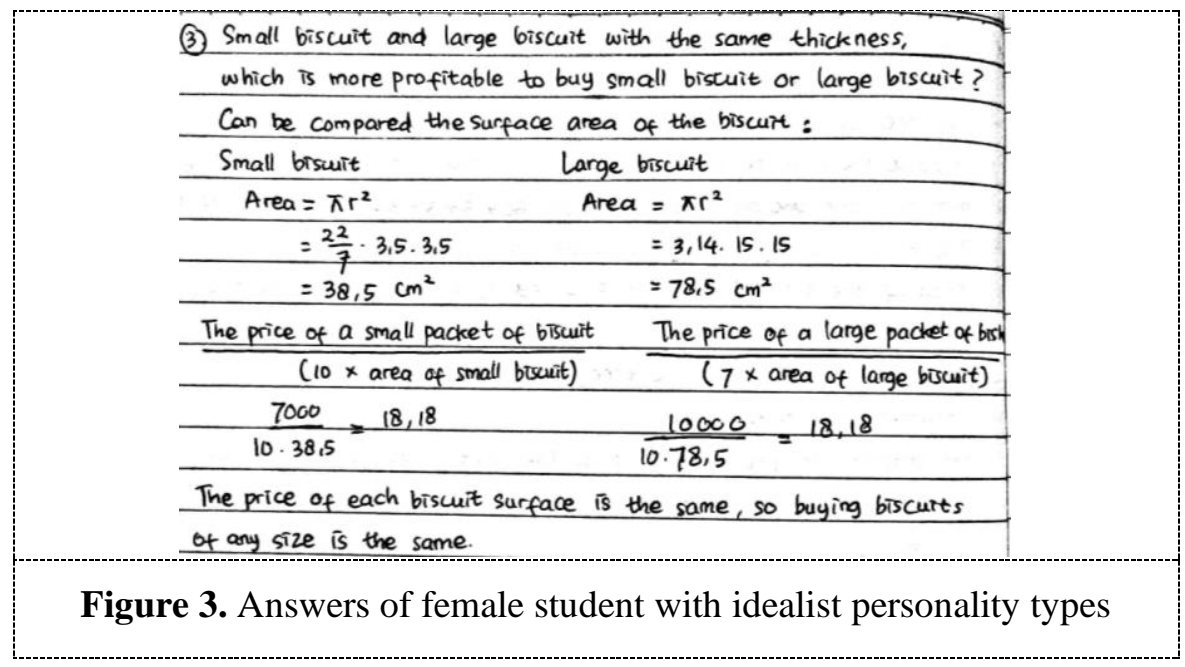

Figure 3 shows that she can evaluate its ideas by applying the concept of circle area to small biscuits and large biscuits, making mathematical models to determine the price for each biscuit surface, 
connecting the ideas that have been put forward with the information in the problem so that it can conclude the results of problem solving to determine whether to buy pack small biscuits or large biscuits. She wrote down his mathematical idea that the price per $\mathrm{cm}^{2}$ of each biscuit surface was the same, so buying small biscuits or large biscuits was the same. However, the results of the interview with her, namely: "I find it difficult to imagine this problem, so I need guidance from the teacher, then I understand how to solve it."

\section{Male student with an idealist personality type}

The results of the mathematical communication skills test on the two male students with the idealist personality type are shown in Figure 4-Figure 6.

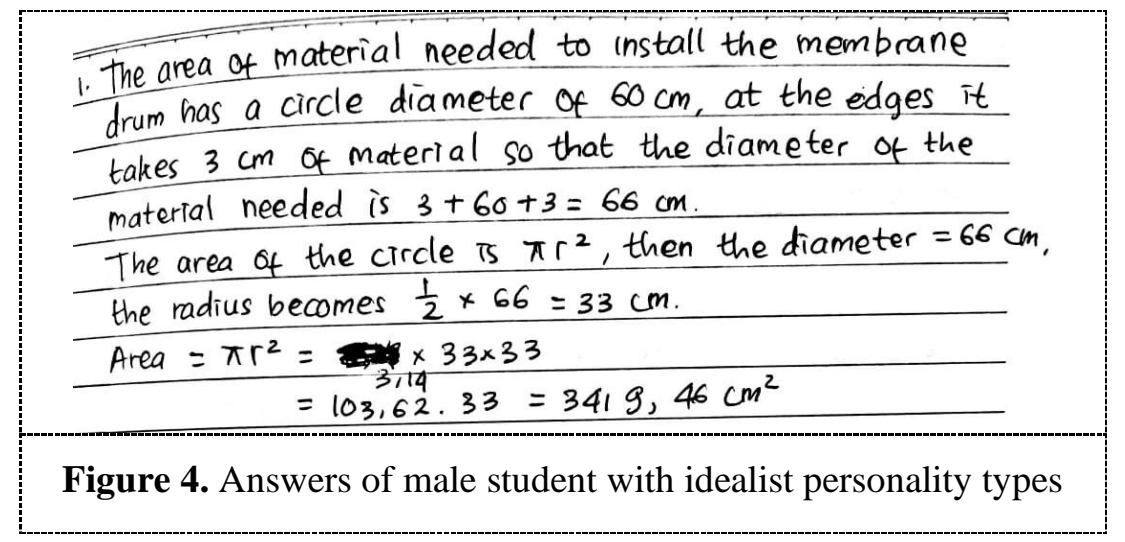

Figure 4 shows that male student is the same as female student for the idealist personality type, which is to describe more words when taking steps to understand the problem of a circular drum membrane. Students are able to write down the steps to determine the area of material needed to cover the drum membrane, determine the diameter in advance from the addition of $3 \mathrm{~cm}$ on the edge of the drum, so that the drum membrane diameter is $66 \mathrm{~cm}$. However, he does not provide conclusions for this problem. He provides explanations in its own language, resulting in a lack of symbolic communication, and looks like it's doubtful because there are some scribbles on the answer. In general, he is able to write steps systematically. This statement is in accordance with the results of an interview with him which said: "I am still confused when to use $\pi=\frac{22}{7}$ or $\pi=3.14$, so I feel unsure." 


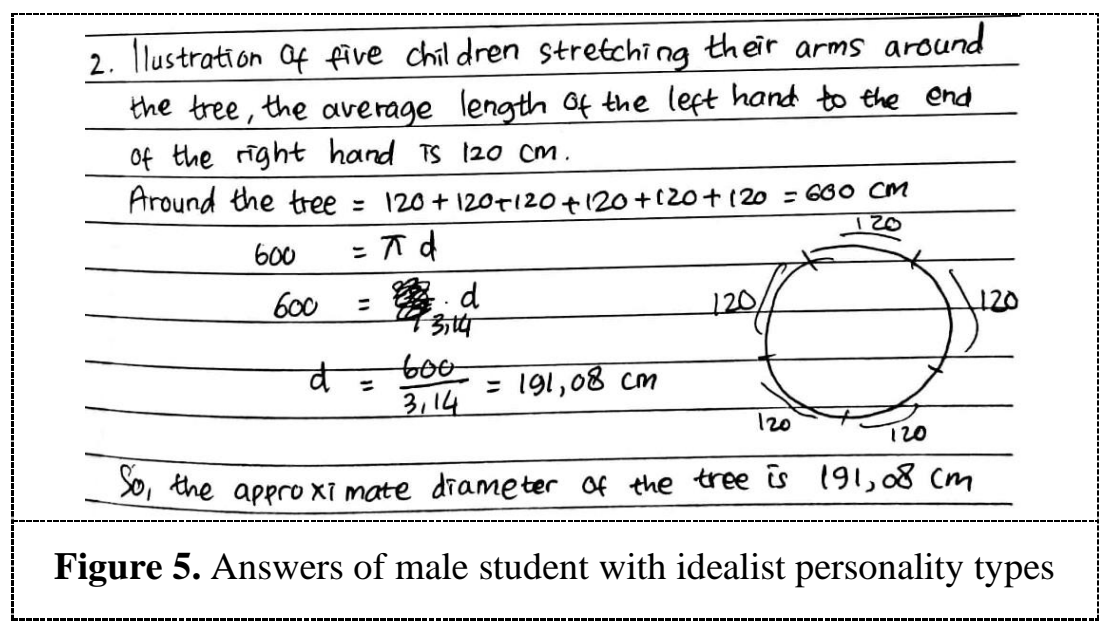

Figure 5 shows that he can express his ideas according to the information obtained in the problem to find the perimeter of the tree by depicting a circle representing five children stretching their arms around a tree. However, he described it without using a compass or coin, making it look less neat. However, he is able to solve and deduce the tree diameter from the circumference of the tree that has been obtained. Such results are based on his statement in which he said: "I think this is in accordance with the illustration of the problem I read, so as long as I draw a circle then I calculate the perimeter of the tree and I find the diameter."

\begin{tabular}{|c|}
\hline 3. Area of small biscuit $=\pi r^{2}=\frac{22}{7} \cdot 3,5 \cdot 3,5=38,5 \mathrm{~cm}^{2}$ \\
\hline Area of large brscuit $=\pi r^{2}=3,14 \cdot 15 \cdot 15=78,5 \mathrm{~cm}^{2}$ \\
\hline The price for a small packet of 10 brscuit is 7000 , \\
\hline while a large packet of 7 is 10000 . \\
\hline The price of a packet of small biskuit $=\frac{7000}{385}=18,18$ \\
\hline (10 $\times$ Area of small biscuit) 38,5 \\
\hline The price of a packet of large biscuit $=\frac{10000}{5}=18,1 \mathrm{~g}$ \\
\hline$(7 \times$ Area of rarge 6iscuit $) \quad 70,5$ \\
\hline The price is the same, so buying small biçait or large \\
\hline biscurt is the same. \\
\hline Figure 6. Answers of male student with idealist personality types \\
\hline
\end{tabular}

Figure 6 shows that he can plan its ideas by applying the concept of circle area to determine the surface area of small and large biscuits. Student can make a mathematical model to determine the price per biscuit from the price per pack and the surface area of the biscuits with precision even though the results written by him look untidy because there are several strokes, so it can be said that he has difficulty solving concrete problems in everyday life. This statement is in accordance with what hesaid, namely: "I am a bit confused. I have to imagine the biscuit problem." 
Each student has the characteristics of their respective personality types, one of the personality type theories used in this article is the Keirsey personality type. It is known that the guardian and artisan personality types are concrete communicators who talk about reality, while the idealist and rational personality types are abstract communicators who talk about ideas. The idealist personality type is a personality type that is able to convey mathematical ideas in the mathematics learning process. Students with idealistic personality types like material about ideas, such as reading and writing. This type also likes to learn in class, because each member wants to get to know each other better (Risky, 2017).

The type of personality that students have will affect their ability, one of which is mathematical communication skills. Therefore, mathematical communication skills will be influenced by student personality types, both male and female students. This is the same as research Aliyah (2019) which states that female students communicate better than male students because the ability to predict problems in male students is still low.

Based on the results of the mathematical communication skills test and interviews previously described, for the first indicator of mathematical communication skills, it can be said that male and female students with idealist personality types have not been able to write ideas mathematically because they describe more words when doing steps to understand the problem. For male and female students, problem solving is written systematically and accurately, but has not yet provided a conclusion on the problem. Female and male students with the Idealist personality type also have difficulty writing conclusions from a problem. The idealist subject's ability to make conclusions in writing using his own words is still lacking (Masrukan, Susilo, \& Pertiwi, 2015). The second indicator, female and male students with idealistic personality types can illustrate a picture of a problem. Male and female students on indicators of mathematical communication in providing ideas in the form of pictures, tables or charts and writing conclusions in accordance with mathematical concepts (Zakiri, Pujiastuti \& Asih, 2018). However, female students with the Idealist personality type are more presentable in drawing, while male students with the Idealist personality type are less neat. On indicators of mathematical expression, female students and male students with idealist personality types can plan their ideas, make mathematical models solve problems correctly and precisely according to the plans made with the assistance of the teacher, because students with idealist personality types find it difficult to imagine questions related to everyday life.

\section{CONCLUSION}

The conclusion in this study is that the mathematical communication skills of female students with idealist personality types are the same as male students with idealist personality types in terms of 
solving problems by stringing words and lack of symbolic communication in mathematics. Each student has advantages and disadvantages in learning, as well as mathematical communication skills of students who have idealistic personalities. Female students are tidier and clearer in expressing ideas obtained from information on questions through pictures compared to male students. In mathematics problems, female students and male students with idealist personality types have weaknesses in solving mathematical problems concretely, students with these idealist personality types need guidance from the teacher in solving concrete problems. Therefore, students with idealistic personality types must be given training so that every student, both male and female, has better mathematical communication skills.

\section{REFERENSI}

Aliyah H. (2019). Students' mathematical communication skills of the straight-line equation based on gender in junior high school Journal of Physics: Conference Series

Aliyah, I. M., Yuhana, Y., \& Santosa, C. A. (2019). Jurnal Dikdaktik Matematika 6(2), 161-178

Aziz. (2014). Jurnal Pendidik Mat 2(1)

Boroujeni, R. \& Hasanimanesh. (2015). J. Theory and Practice in Language Studies 5, 212-29

Fachrurazi. (2011). Penerapan Pembelajaran Berbasis Masalah Untuk Meningkatkan Kemampuan Berpikir Kritis dan Komunikasi Matematis Peserta didik Sekolah Dasar Jurnal Edisi Khusus, 1

Hodiyanto. (2017). Jurnal AdMathEdu 7(1), ISSN 2088-687X

Keirsey, D., dan Bates. (1984). California Promotheus Nemesis Book Company

Masrukan, Susilo B. E. \& Pertiwi A. D. (2015). Analysis of Mathematical Communication Ability Through $4 \mathrm{~K}$ Model Based on $7^{\text {th }}$ Grades' Personality Types International Journal of Education and Research 3(7)

Melya, L. \& Supriadi N. (2018). Desimal: Jurnal Matematika 1(3)

NCTM 2000 Principles and Standards for School Mathematics Reston (Virginia: NCTM)

Nugraha, T. H., \& Pujiastuti, H. (2019) Edumatica 9(1), 1-7

Pratiwi, D. D. (2015) Al-Jabar: Jurnal Pendidikan Matematika 6(2)

Rahmayani, D. (2014). FIP Universitas Muhammadiyah Jakarta

Risky, A. D. (2017) Profil Penalaran Siswa SMP dalam Menyelesaikan Masalah Matematika Ditinjau dari Tipe Kepribadian Jurnal Mathedunesa

Sari, D.S., Kusnandi, K., dan Suhendra, S. (2017). Journal of Physics Conf. Series 895012083 1-7

Sulvian \& Mousley (1996). Technology in Mathematics Education Melbourne: Merga

The literacy and Numeracy Secretariat. (2010). Capasity Building Series special edition 13 
Wijaya, H. P. I., Sujadi, I., \& Riyadi, (2016). Jurnal Elektronik Pembelajaran Matematika 4(9), 778788

Zakiri, I. K., Pujiastuti E. \& Asih T. (2018). The mathematical communication ability based on gender difference on students of XI grade by using problem-based learning model assisted by probing prompting technique UNNES Journal of Mathematics Education 7(2) 